\title{
Disease Phenotype of Virus-Infected Helminthosporium victoriae Is Independent of Overexpression of the Cellular Alcohol Oxidase/RNA-Binding Protein Hv-p68
}

\author{
Tianyong Zhao, Wendy M. Havens, and Said A. Ghabrial
}

Department of Plant Pathology, University of Kentucky, Lexington 40546.

Accepted for publication 29 November 2005.

\section{ABSTRACT}

Zhao, T., Havens, W. M., and Ghabrial, S. A. 2006. Disease phenotype of virus-infected Helminthosporium victoriae is independent of overexpression of the cellular alcohol oxidase/RNA-binding protein Hv-p68. Phytopathology 96:326-332.

The cellular protein Hv-p68 is a novel alcohol oxidase/RNA-binding protein that is overexpressed in virus-infected isolates of the plant-pathogenic fungus Helminthosporium victoriae (teleomorph: Cochliobolus victoriae). Overproduction of Hv-p68 has been hypothesized to lead to the accumulation of toxic aldehydes and to induce the disease phenotype associated with the virus-infected isolates. We overexpressed the $H v-p 68$ gene in virus-free isolates and evaluated the morphology of the resulting colonies. We cloned and sequenced the $H v-p 68$ genomic DNA, which contains five introns and the complete $H v$-p 68 coding sequence. Vectors for overexpression of the $\mathrm{Hv}-\mathrm{p} 68$ gene were constructed with either $\mathrm{Hv}$ p68 cDNA or the intron-containing $H v-p 68$ genomic DNA. Expression of
$H v$-p68 was significantly higher if the genomic sequence was used for transformation than if the cDNA sequence was used. The virus-free fungal transformants that overexpressed $H v-p 68$ gene did not exhibit the disease phenotype. In contrast, these transformants showed enhanced growth rates when compared with the nontransformed and empty vector controls. Interestingly, overexpression of $H v-p 68$ in a fungal isolate infected with both the totivirus Helminthosporium victoriae $190 \mathrm{~S}$ virus (Hv190SV) and the chrysovirus Helminthosporium victoriae $145 \mathrm{~S}$ virus (Hv145S) showed enhanced accumulation of the Hv145SV doublestranded (ds)RNA, but not of the Hv190SV. These results are consistent with an earlier report that Hv-p68 co-purified with viral dsRNA, mainly that of the Hv145SV. Elucidation of the role of Hv-p68 in disease induction is important for an understanding of host-virus interactions in this fungus-virus system.

Additional keywords: fungal transformation.
The plant-pathogenic fungus Helminthosporium victoriae (teleomorph: Cochliobolus victoriae) was first described in 1946 as the causal agent of Victoria blight of oat (12). A transmissible disease of $H$. victoriae was discovered in 1959 and its viral etiology is known $(6,7)$. Diseased $H$. victoriae isolates have reduced growth, excessive sectoring, aerial mycelial collapse, and generalized lysis $(6,16)$. The disease phenotype of $H$. victoriae is of special interest because the diseased isolates are hypovirulent and because they contain two isometric viruses with double-stranded (ds)RNA genomes (8): the totivirus Helminthosporium victoriae 190S virus (Hv190SV) and the chrysovirus Helminthosporium victoriae $145 \mathrm{~S}$ virus (Hv145SV).

Hv-p68 is a cellular multifunctional protein that is overexpressed in virus-infected fungal isolates and co-purifies with virus dsRNA, mainly that of Hv145SV (21). The $H v-p 68$ cDNA has been sequenced and $H v-p 68$ transcription is 10 - to 20 -fold higher in virus-infected isolates (20). Hv-p68 belongs to the large family of flavin-adenine dinucleotide (FAD)-dependent glucosemethanol-choline (GMC) oxidoreductases, with 67 to $70 \%$ sequence identity to the alcohol oxidases of methylotrophic yeasts (20). Alcohol oxidases from methylotrophic yeasts or filamentous fungi usually oxidize primary alcohols (and, occasionally, aromatic alcohols) irreversibly to toxic aldehydes $(17,24)$. Overproduction of Hv-p68 and concomitant accumulation of toxic intermediates was proposed as a possible mechanism underlying the disease phenotype of virus-infected $H$. victoriae isolates (20).

Corresponding author: S. A. Ghabrial; E-mail address: saghab00@uky.edu

DOI: 10.1094/PHYTO-96-0326

(C) 2006 The American Phytopathological Society
The objectives of our study were to (i) clone and sequence $H v$ p68 genomic DNA, (ii) transform virus-free isolates of $H$. victoriae with recombinant vectors containing $H v$-p68 genomic DNA or cDNA, and (iii) analyze the resultant transformants for $H v-p 68$ expression level and colony morphology. Our major goal was to test the hypothesis that overproduction of the Hv-p68 protein in a virus-free isolate would result in the disease phenotype.

\section{MATERIALS AND METHODS}

Fungal isolates. Unless otherwise indicated, the virus-free $H$. victoriae wild-type (WT) strain B2ss (ATCC 42020) was used in all transformation experiments with recombinant plasmids containing the $H v-p 68$ gene constructs. The fungal cultures were maintained on potato dextrose agar containing $0.5 \%(\mathrm{wt} / \mathrm{vol})$ yeast extract (PDAY) (Difco Laboratories, a subsidiary of Becton, Dickinson and Co., Spark, MD). In some experiments, the virusinfected $H$. victoriae (Inf) strain (ATTC 42018) was used.

Plasmids and bacterial strains. Escherichia coli strain DH5 $\alpha$ was used to propagate plasmids. Cosmid vector pMLF2 (2) was provided by Mark Farman (University of Kentucky). Plasmid pBG (22), which contains the bar gene and gpdl promoter from C. heterostrophus, was provided by Olen Yoder (Diversa Corp., San Diego, CA).

Polymerase chain reaction amplification and cloning of fulllength $H v-p 68$ genomic DNA and cDNA. $H$. victoriae genomic DNA was isolated from 14-day-old mycelium grown on potato dextrose broth supplemented with yeast extract (PDBY) medium, as described previously (20). Polymerase chain reaction (PCR) was carried out with $H$. victoriae genomic DNA as a template and a pair of primers (forward primer, 5'-CTTGAGCCATCAGA- 
ATGACG-3'; reverse primer, 5' -ATCCTCTTTTCGCATCAGTC$3^{\prime}$ ), based on the sequences of the $5^{\prime}$ and $3^{\prime}$ untranslated regions (UTRs) of a previously characterized $H v-p 68$ cDNA clone (GenBank accession no. AF232903). Platinum High Fidelity Taq DNA polymerase was used for PCR and cycling conditions were $94^{\circ} \mathrm{C}$ for $2 \mathrm{~min}$ followed by 35 cycles of $94^{\circ} \mathrm{C}$ for $30 \mathrm{~s}, 55^{\circ} \mathrm{C}$ for $30 \mathrm{~s}$, and $72^{\circ} \mathrm{C}$ for $3 \mathrm{~min}$ ). PCR products were purified with PCR purification Kit (Qiagen Valencia, CA) and cloned into pGEM-T Easy vector (Promega Corp., Madison, WI). Hv-p68 cDNA was amplified by PCR with the same primer pair as used for the genomic DNA and recombinant vector pZL1 (20), containing $\mathrm{Hv}$ p 68 cDNA with the entire $H v-p 68$ open reading frame (ORF) and portions of the $5^{\prime}$ and $3^{\prime}$ UTRs as a template, and cloned into the pGEM-T Easy vector. Two each of the full-length genomic and cDNA $H v$-p68 clones, inserted in the pGEM-T Easy vector, were sequenced on both strands using universal primers and genespecific "walking" primers.

Plasmid constructs for overexpression of $\mathrm{H} v$-p68. Plasmid pBG was digested by BamHI to excise the bar gene, and the large fragment containing the gpdl promoter was purified and selfligated to generate plasmid $\mathrm{pG}$. The gpdl promoter was excised as a HindIII-NotI fragment from plasmid $\mathrm{pG}$ and inserted into the respective sites of plasmid pMLF2. Aspergillus nidulans trpC terminator was obtained by PCR with pMLF2 as the template and a pair of primers (forward primer, 5'-GGCCGCGGGGGCCCATGTCAACA-AGA-3'; reverse primer, 5'-GGCCGCGGCCGAGTGGAGATGTGGAG-3'), based on the sequences of the ends of the $\operatorname{trpC}$ terminator. A restriction site for SacII was included in each primer (written in bold) to facilitate cloning. The PCR product was purified with a PCR purification kit (Qiagen), digested with $S a c$ II, and then purified on a gel. The purified $\operatorname{trpC}$ terminator fragment was inserted downstream of the $H v-p 68$ gene in the pGEM-T Easy vector. The orientation of the $\operatorname{trpC}$ terminator was determined by restriction enzyme analysis. The Hv-p68-trpC terminator fragment was released by NotI digestion and ligated into a dephosphorylated NotI-digested pMLF2-gpdl vector. The orientation of $H v-p 68$ was determined by restriction enzyme analysis and verified by sequencing.

Fungal transformation. Protoplasts were prepared from H. victoriae mycelia as described by Yoder (25), except that Glucanex (Sigma-Aldrich, St. Louis) at $10 \mathrm{mg} / \mathrm{ml}$ replaced Novozyme 234 in the enzyme osmoticum solution $(0.7 \mathrm{M} \mathrm{NaCl})$. For transformation, $\approx 5 \times 10^{7}$ protoplasts in $100 \mu$ l of STC buffer (1.2 M sorbitol, $10 \mathrm{mM}$ Tris- $\mathrm{HCl}, \mathrm{pH} 7.5$, and $10 \mathrm{mM} \mathrm{CaCl}$ ) were incubated with $10 \mu \mathrm{g}$ of plasmid DNA at room temperature $\left(21\right.$ to $23^{\circ} \mathrm{C}$ ) for $20 \mathrm{~min}$. Polyethylene glycol (PEG) solution (60\% PEG 4000, $10 \mathrm{mM}$ Tris- $\mathrm{HCl}, \mathrm{pH} 7.5$, and $50 \mathrm{mM} \mathrm{CaCl}$ ) then was added in three steps $(200,200$, and $800 \mu$ l, respectively) during a 20-min incubation at room temperature. After adding $10 \mathrm{ml}$ of STC, the mixture was centrifuged at $3,000 \times g$ for $10 \mathrm{~min}$ and the protoplasts resuspended in $500 \mu \mathrm{l}$ of STC. Regeneration medium ( $10 \mathrm{ml}$ of $0.1 \%$ yeast extract, $0.1 \%$ casein hydrolysate, $1 \mathrm{M}$ sucrose, and $1.75 \%$ agar), which was kept at $48^{\circ} \mathrm{C}$, was added and the mixture was poured into petri dishes. The plates were incubated at $30^{\circ} \mathrm{C}$ for $16 \mathrm{~h}$ and then overlaid with $10 \mathrm{ml}$ of $1 \%$ agar containing hygromycin B at $100 \mu \mathrm{g} / \mathrm{ml}$. After 6 days, colonies were counted and transferred to fresh regeneration medium containing hygromycin B $(50 \mu \mathrm{g} / \mathrm{ml})$. The transformants were subjected to two rounds of single-spore isolation to ensure nuclear homogeneity.

Southern blot hybridization analysis. Genomic DNA was digested with restriction endonucleases, size-fractionated on a $0.7 \%$ agarose gel in $1 \times$ Tris-acetate-EDTA (19) and transferred to a nylon membrane (Hybond $\mathrm{N}^{+}$; Amersham, Piscataway, NJ). The DNA was cross-linked and the membrane was prehybridized at $65^{\circ} \mathrm{C}$ for $12 \mathrm{~h}$ in $6 \times \mathrm{SSPE}(1 \times \mathrm{SSPE}$ is $0.18 \mathrm{M} \mathrm{NaCl}, 10 \mathrm{mM}$ $\mathrm{NaPO}_{4}$, and $1 \mathrm{~nm}$ EDTA [pH 7.7]), 5× Denhardt's solution, $0.5 \%$ sodium dodecyl sulfate (SDS), and boiled, sheared salmon sperm
DNA at $100 \mu \mathrm{g} / \mathrm{ml}$ (19). The blot was hybridized with a randomly primed $\left[\alpha-{ }^{32} \mathrm{P}\right] \mathrm{dCTP} H v$-p68 cDNA probe for 16 to $18 \mathrm{~h}$. Blots were washed using high stringency conditions $(2 \times$ SSC $[1 \times$ SSC is $0.15 \mathrm{M} \mathrm{NaCl}$ plus $0.015 \mathrm{M}$ sodium citrate], $0.1 \% \mathrm{SDS}$ at room temperature for $10 \mathrm{~min}$; $0.1 \times \mathrm{SSC}, 0.1 \% \mathrm{SDS}, 65^{\circ} \mathrm{C}$ for $30 \mathrm{~min}$ ) and exposed to a phosphorimager screen. The images were visualized with a PhosphorImager 445 SI system (Amersham).

RNA isolation and northern hybridization analysis. Total RNA was extracted from mycelia with a phenol/chloroform proto$\mathrm{col}$, as described previously (20). Total RNA $(20 \mu \mathrm{g})$ was fractionated on a denaturing agarose gel and transferred to a nylon membrane $\left(\right.$ Hybond $\mathrm{N}^{+}$) in $10 \times \mathrm{SSC}(\mathrm{pH} 7)$ for $16 \mathrm{~h}$, and then cross-linked. After rinsing the membranes in $2 \times \mathrm{SSC}$, blots were placed in prehybridization solution $(50 \%$ formamide; $5 \times$ Denhardt's solution; boiled, sheared salmon sperm DNA at $100 \mu \mathrm{g} / \mathrm{ml}$; $0.2 \% \mathrm{SDS}, 6 \times \mathrm{SSC} ; \mathrm{pH} 7.0)$ for $12 \mathrm{~h}$ at $42^{\circ} \mathrm{C}$. Radiolabeled [ $\left.\alpha-{ }^{32} \mathrm{P}\right]$ dCTP $H v-p 68$ cDNA probe was hybridized to the blots for at least $16 \mathrm{~h}$ at the same temperature, and washed as described for the Southern blots. The probe was removed from the membrane by washing in $0.1 \times \mathrm{SSC}, 0.1 \% \mathrm{SDS}$ at room temperature for $10 \mathrm{~min}$, followed by washing in $0.1 \mathrm{~N} \mathrm{NaOH}, 0.2 \% \mathrm{SDS}$ at room temperature for $4 \mathrm{~min}$ and, finally, in $0.2 \mathrm{M}$ Tris- $\mathrm{HCl}$ $(\mathrm{pH} 7.5), 0.1 \times \mathrm{SSC}, 0.2 \% \mathrm{SDS}$ at room temperature for $20 \mathrm{~min}$. The membrane then was probed with a $\operatorname{trp} \mathrm{C}$ probe, as described above.

Western blot analysis. Protein was extracted with a modification of the procedure of Osherov and May (15). Briefly, lyophilized mycelium (10 mg) was powdered in liquid $\mathrm{N}_{2}$ and mixed with $0.5 \mathrm{ml} 10 \%$ trichloroacetic acid and vortexed. After incubation at room temperature for $5 \mathrm{~min}$, the mixture was centrifuged at $12,000 \times g$ for $5 \mathrm{~min}$, washed three times with $90 \%$ acetone plus $20 \mathrm{mM} \mathrm{HCl}$, and air dried. The dry pellet was suspended in $0.2 \mathrm{ml}$ of sample buffer (1\% SDS, $9 \mathrm{M}$ urea, $25 \mathrm{mM}$ Tris- $\mathrm{HCl}$, $1 \mathrm{mM}$ EDTA, and $0.7 \mathrm{M}$ 2-mercaptoethenol). The suspension was vortexed for $1 \mathrm{~min}$ and then boiled for $2 \mathrm{~min}$; vortexing and boiling was repeated once. The suspension was centrifuged at $10,000 \times g$ for $5 \mathrm{~min}$ and 20 - $\mu$ l samples of supernatant were loaded onto a $10 \%$ SDS-polyacrylamide gel. Western blot analysis was performed as described previously (10).

Measurement of colony growth. Colonies derived from single spores of WT and from each transformant were transferred to three PDAY plates. Diameters of the colonies were measured at day 9. Growth measurements were subjected to statistical analysis using analysis of variance and mean separation.

\section{RESULTS}

PCR amplification, cloning, and sequencing of $\mathrm{Hv}$-p68 genomic DNA. A 2.3-kb PCR product was obtained when using the $H$. victoriae genomic DNA as the template and the primers corresponded to the $5^{\prime}$ and $3^{\prime}$ sequences flanking the $H v-p 68 \mathrm{ORF}$ (GenBank accession no. AF232903). This sequence contains five introns that are in general agreement with the filamentous fungi consensus sequences (3) for 5'-splice junctions (5'-GTDHSY; where $\mathrm{D}=\mathrm{A}, \mathrm{G}$, or $\mathrm{T} ; \mathrm{H}=\mathrm{A}, \mathrm{C}$, or $\mathrm{T} ; \mathrm{S}=\mathrm{C}$ or $\mathrm{G}$; and $\mathrm{Y}=\mathrm{C}$ or $\mathrm{T}), 3^{\prime}$-splice sites (5'-YAG), and internal putative lariat formation elements ( $5^{\prime}$ NNYTNAY; where $\mathrm{N}=$ any nucleotide). The nucleotide positions of the five introns relative to the start codon (ATG at positions +1 to +3 ) are: intron $1,+19$ to +77 ; intron $2,+357$ to +408 ; intron $3,+799$ to +848 ; intron $4,+1091$ to +1141 ; and intron $5,+1903$ to +1983 .

The sequence of the $H v-p 68$ genomic clone, without introns, is identical to that of the previously reported full-length $\mathrm{Hv}-\mathrm{p} 68$ cDNA clone (20). Furthermore, it is identical to the corresponding sequence of the partial genomic clone of $H v-p 68$ that was generated and sequenced in a previous study (20). We also have cloned and sequenced a genomic DNA fragment that contains part of the $5^{\prime}$ end region of the $H v-p 68$ gene and flanking sequence 
(2,400 bp upstream the initiation codon ATG), which was obtained by screening a genomic DNA library of $C$. victoriae (P. de Sá and S. A. Ghabrial, unpublished data). Moreover, using inverse PCR (19), the sequence of a genomic DNA fragment that borders the $3^{\prime}$ end of $H v-p 68$ (1,920 bp downstream of the termination codon TAA) was obtained. The sequence of the fulllength $H v$-p68 genomic DNA along with the $5^{\prime}$ and $3^{\prime}$ flanking sequences (total of $6.6 \mathrm{kbp}$ ) were deposited in the GenBank under accession number AY497010.

Construction of transformation vectors. Two recombinant vectors were constructed using the $C$. heterostrophus gpd 1 promoter to drive either $H v-p 68$ genomic DNA or $H v-p 68$ cDNA (Fig. 1A). Both expression vectors A and B as well as the empty vector control $(\mathrm{C})$ were used to transform the $H$. victoriae WT strain B2-ss (ATCC 42020). From over 100 transformants that originally were subjected to Southern hybridization analysis, $5 \mathrm{Hv}$-p68 genomic DNA fungal transformants, $3 \mathrm{Hv}$-p68 cDNA

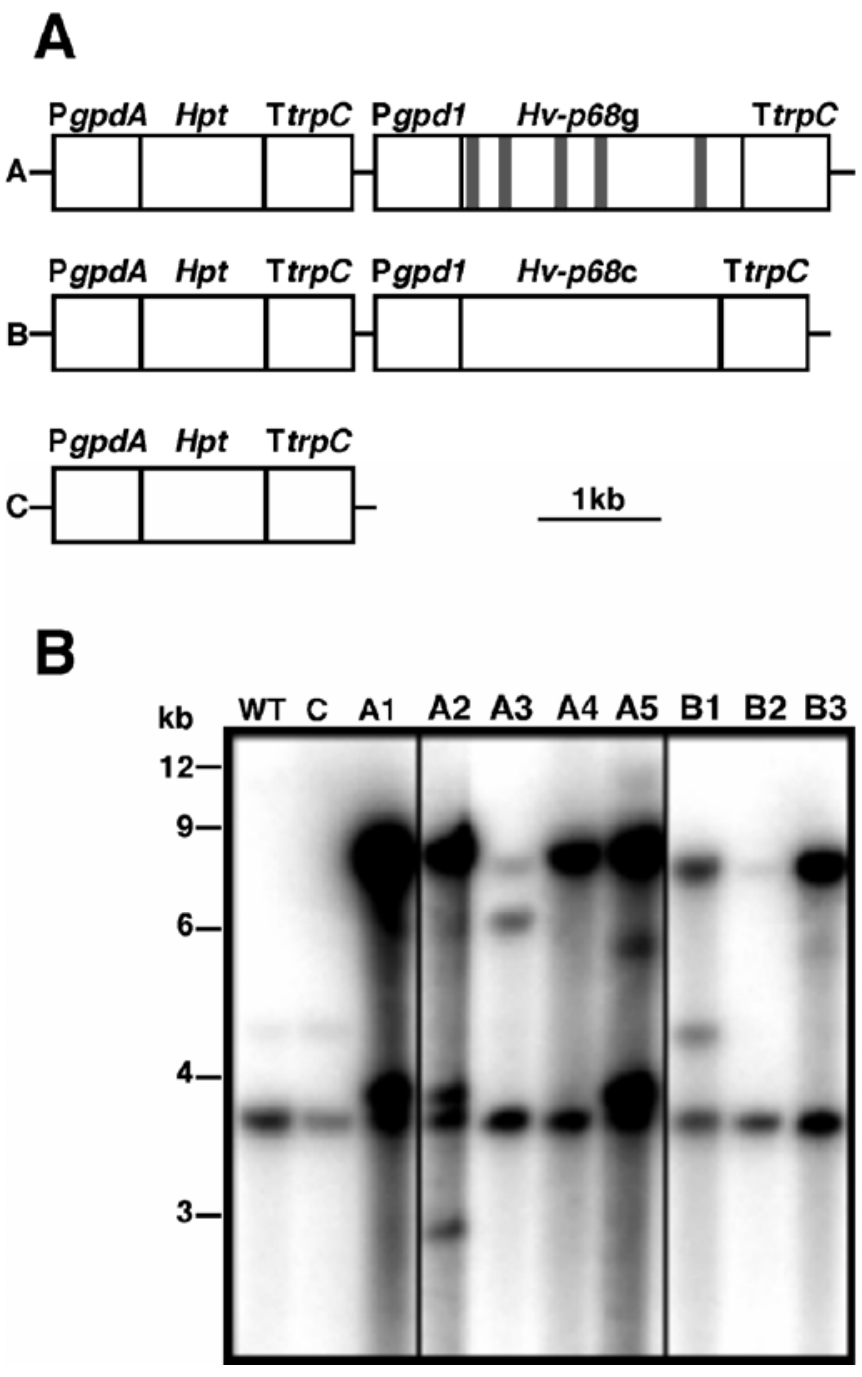

Fig. 1. Southern blot hybridization analysis of virus-free $H v-p 68$ transformants. A, Schematic representation of the plasmid constructs used for fungal transformation with $H v-p 68$ genomic DNA (A), $H v-p 68$ cDNA (B), and empty vector control (C). Abbreviations: PgpdA, promoter of gpdA from Aspergillus nidulans; Pgpd1, promoter of gpd 1 from Cochliobolus heterostrophus; TtrpC: terminator of $\operatorname{trpC}$ gene in A. nidulans; Hpt, bacterial hygromycin B phosphotransferase gene; $H v-p 68 g, H v-p 68$ genomic DNA containing five introns; and $H v-p 68 \mathrm{c}, H v-p 68$ cDNA. B, Southern hybridization analysis of transformants. Genomic DNA $(1.5 \mu \mathrm{g})$ was digested with PstI and separated on $0.7 \%$ agarose gel, then transferred onto a nylon membrane and hybridized with a ${ }^{32} \mathrm{P}$-labeled $H v$-p68 cDNA probe. WT, nontransformed virus-free isolate; C, empty vector transformant control; A1 to A5, Hv-p68 genomic DNA transformants; and B1 to $\mathrm{B} 3, H v-p 68$ cDNA transformants. transformants, and 1 empty vector transformant control were studied further.

Analysis of virus-free transformants. Southern blot analysis of the $H v-p 68$ gene indicated that multiple copies of the $H v-p 68$ transgene were detected in several transformants (Fig. 1B). Based on differences in hybridization banding patterns and intensity of hybridization signals, five genomic $H v$-p68 transformants (A1 to A5) and three $H v-p 68$ cDNA transformants (B1 to B3) were selected for further analysis. The differences in banding pattern among the transformants suggest that all the transformants tested were independent. The $H v-p 68$ cDNA probe hybridized with a $3.6-\mathrm{kb}$ fragment, which is common to the WT and all transformants, including the empty vector transformant. This $3.6-\mathrm{kb}$ fragment contains the endogenous $H v-p 68$ gene and portions of the $5^{\prime}$ and $3^{\prime}$ flanking sequences. Thus, the transforming DNA, likely inserted at ectopic locations, neither disrupted nor replaced the native sequence.

In northern hybridizations with total RNA probed with $H v-p 68$ cDNA, transformants with the $H v-p 68$ genomic DNA expression vector accumulated significantly higher levels of $H v$-p68 transcript than did those transformed with the $H v-p 68$ cDNA (Fig. $2 \mathrm{C}$ ). The predicted size of $H v$-p68 mRNA is $\approx 2.1 \mathrm{~kb}(20)$, but the major Hv-p68 transcript was $2.8 \mathrm{~kb}$ (Fig. 2C), suggesting that the transcript may contain the $\operatorname{trp} C$ terminator sequence $(0.7 \mathrm{~kb})$ in addition to $H v-p 68$ mRNA. This arrangement was confirmed when the northern blot was hybridized with a $\operatorname{trp} C$ terminator-

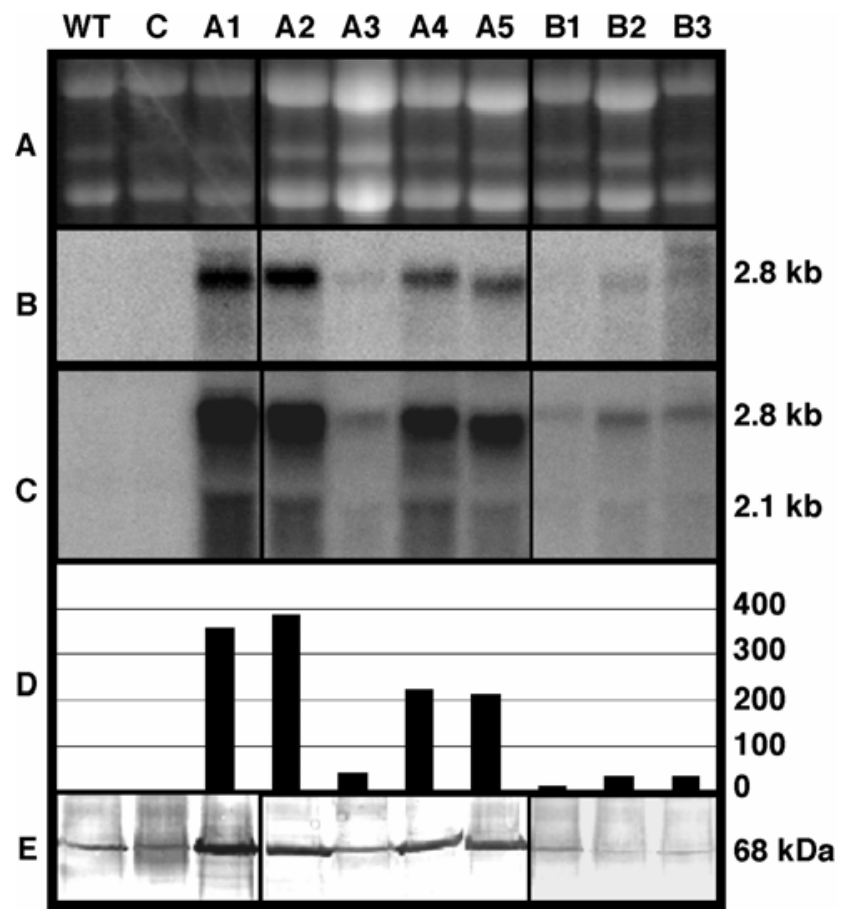

Fig. 2. Analysis of $H v-p 68$ expression in virus-free nontransformed wild-type (WT) and $H v-p 68$ transformants. A to D, Northern blot hybridization analysis of total RNA extracted from WT, empty vector control (C), and $H v-p 68$ transformants. Total RNA ( $20 \mu \mathrm{g})$ was fractionated by electrophoresis on a denaturing agarose gel and blotted onto a nylon membrane. A, Ethidium bromide staining of rRNA is shown as loading control. The northern blot was hybridized first with a ${ }^{32} \mathrm{P}$-labeled $H v-p 68$ cDNA probe $(\mathbf{C})$; then, the probe was stripped off the membrane and the blot was hybridized with the $\operatorname{trpC}$ terminator probe (B). The images generated by exposure of the northern blot to a phosphorimager screen (shown in C) were visualized by Phosphorimager 445 S1 system (Molecular Dynamics) and quantified with the gel ImageQuant 5.0 program (D). E, Western blot analysis. Protein samples from the various transformants were fractionated on a $10 \%$ sodium dodecyl sulfate-polyacrylamide gel and transferred to an Immobilon membrane. The blot was probed with an antiserum raised against Hv-p68. WT, nontransformed virus-free isolate; C, empty vector transformant control; A1 to A5, $H v-p 68$ genomic DNA transformants; and $\mathrm{B} 1$ to $\mathrm{B} 3, H v-p 68$ cDNA transformants. 
specific probe (Fig. 2B). Apparently only a small fraction of the $H v-p 68$ pre-mRNA was processed to the expected $2.1-\mathrm{kb} H v-p 68$ mRNA (Fig. 2C).

Densitometry of the northern blot shown in Figure 2C indicated that transformants A1, A2, A4, and A5 accumulated at least 200 times more of the 2.8-kb Hv-p68 transcript than did transformant B1 (Fig. 2D). The level of $H v-p 68$ gene transcription in the $H v$ p68 genomic DNA transformants was correlated with the number of inserted copies of the transforming DNA, as inferred from the intensity of the hybridization bands (compare Figs. 1B and 2C). There was no such relationship for the $H v-p 68$ cDNA transformants. Furthermore, the accumulation levels of the Hv-p68 protein in the transformants were consistent with the northern hybridization results (Fig. 2E).

Although the 2.1-kb $H v-p 68$ mRNA generated from the endogenous $H v-p 68$ gene was not evident in northern blots of total RNA from the nontransformed WT isolate after a short exposure (Fig. 2), it was readily detected in overexposed blots (Fig. 3A and $\mathrm{B})$. Interestingly, the $2.1 \mathrm{~kb}$ was not detected in overexposed blots of some $H v$-p68 transformants (e.g., B1 and A3) (Fig. 3A), suggesting that the expression of the endogenous $H v-p 68$ gene was downregulated or shut off in these transformants. Even though the endogenous $H v$-p 68 gene was downregulated or completely shut off in transformants B1 and A3 (Fig. 3A), the Hv-p68 protein still was produced from the $H v-p 68$ transgene (Fig. 2E). Thus, the $2.8-\mathrm{kb}$ transcript in these transformants has been processed to remove the introns prior to its export to the cytoplasm.

We compared the levels of $H v-p 68$ transcript in a naturally occurring virus-infected isolate with that in virus-free transformants overexpressing $H v-p 68$ (Fig. 3B). Northern blot hybridization showed that significantly higher levels of $H v-p 68$ transcript accumulated in some of the transformants transformed with genomic $H v-p 68$ (e.g., transformant A1) than in the virusinfected isolate (Fig. 3B). The Hv-p68 protein is known to accumulate to higher levels in virus-infected $H$. victoriae isolates; the amounts of Hv-p68 detected in virus-infected isolates are three- to fivefold higher than those from virus-free isolates (21). Thus, it was of interest to compare the relative amount of Hv-p68 in the virus-infected isolate to that in $H v-p 68$ genomic DNA transformants. The results of western blot analysis showed that higher levels of Hv-p68 accumulation occurred in the transformants that overexpressed $H v-p 68$ than in the virus-infected isolate (Fig. 3C). Densitometry of the western blot indicated that the level of Hv-p68 in the Hv-p68 transformant A1 was approximately fourfold higher than that in the virus-infected isolate (data not shown). Colonies of transformant A1 had none of the morphological features of the diseased virus-infected isolates (stunting, sectoring, mycelial collapse, and reduced sporulation) (Fig. 4).

Colony morphology and growth differences among transformants. Colony diameter (in millimeters) of transformants that overexpressed $H v$-p68 (e.g., A1, A2, A4, and A5) was significantly larger than that of WT and empty vector transformant $\mathrm{C}$ (Table 1). The colony morphology of the vector-only control (C) was similar to that of the WT, and none of the transformants that overproduced the Hv-p68 protein exhibited the disease phenotype (Fig. 4).

Transformation of a virus-infected isolate with the $\mathrm{Hv}-\mathrm{p68}$ genomic DNA. Hv-p68 is an RNA-binding protein that co-purifies with viral dsRNA $(20,21)$. Thus, it was of interest to assess the effect of transforming a virus-infected isolate (Inf) with the $H v-p 68$ genomic DNA on colony morphology and virus content. Because of the debilitation of the Inf isolate, the yield of the generated protoplasts was poor and only a limited number of hygromycin-resistant transformants were recovered. Of these, two transformants, designated T1 and T2, were verified by Southern hybridization analysis to contain additional copies of $H v-p 68$, as described for the virus-free transformants, and used for further analysis. Northern blot hybridization revealed that the $H v-p 68$ transcript was significantly higher in transformants $\mathrm{T} 1$ and $\mathrm{T} 2$ than that of the nontransformed Inf isolate (Fig. 5B; blot probed with the $H v-p 68$ cDNA probe). Interestingly, the accumulation levels of Hv145SV dsRNAs in transformants T1 and T2 were two- to threefold higher than those in the nontransformed Inf isolate (Fig. 5B; blots probed with cloned cDNA probes to $145 \mathrm{~S}$ dsRNA1 and dsRNA2). The accumulation level of the Hv190SV dsRNA in T1 and T2, on the other hand, was similar to that in the nontransformed virus-infected isolate (Fig. 5B; blot probed with a cloned cDNA probe to Hv190SV dsRNA). The Inf transformants that overexpressed $H v-p 68$ exhibited typical disease phenotype and were more or less similar to the WT Inf isolates (data not
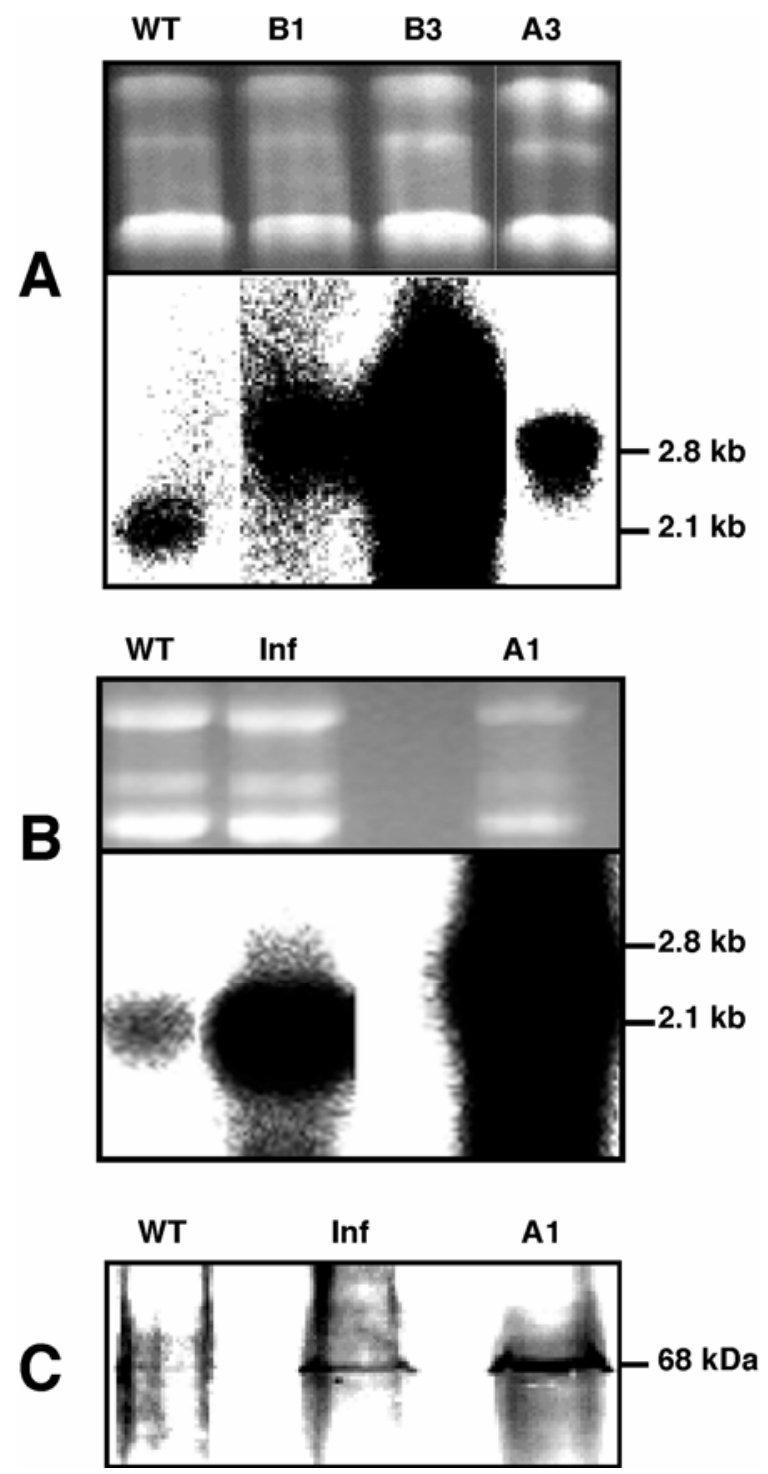

Fig. 3. Comparative analysis of $H v-p 68$ expression in virus-infected and virusfree $H v-p 68$ transformants. A, Northern blot analysis of total RNA extracted from a nontransformed (WT) and $H v$-p68-transformed virus-free isolates (B1, B3, and A3). B, Northern blot analysis of total RNA extracted from virusfree nontransformed (WT), virus-infected (Inf), and virus-free $H v$-p68 transformant overexpressing $H v-p 68$ (transformant A1). In $\mathbf{A}$ and $\mathbf{B}$, total RNA $(20 \mu \mathrm{g})$ was fractionated by electrophoresis on a denaturing agarose gel, blotted onto nylon membranes, and the blots were hybridized with ${ }^{32} \mathrm{P}$ labeled $H v$-p 68 cDNA probes (lower panels). Ethidium bromide staining of rRNA is shown in the upper panel as loading control. C, Comparative accumulation levels of the Hv-p68 protein in a virus-free WT, virusinfected isolate (Inf), and virus-free $H v-p 68$ genomic DNA transformant (A1). Equal amounts of total soluble proteins $(100 \mu \mathrm{g})$, as determined by a Bio-Rad protein assay (Bio-Rad, Hercules, CA), were subjected to western blot analysis. 
shown). Critical comparison in growth rates and symptom severity between the Hv-p68 transformed and nontransformed Inf isolates was not possible because of the variation in symptom severity among WT Inf isolates and because of the limited number of transformants available.

\section{DISCUSSION}

Hv-p68 is a novel alcohol oxidase/RNA-binding protein in a filamentous fungus $(20,21)$. Overproduction of the Hv-p68 in virus-infected isolates of $H$. victoriae was hypothesized to play a role in viral pathogenesis (20). Hv-p68 belongs to the large family of FAD-dependent GMC oxidoreductases, with 67 to $70 \%$ sequence identity to the alcohol oxidases of methylotrophic yeasts (20). Hv-p68, however, shows only limited methanol-oxidizing activity and its expression is not induced in cultures supplemented with methanol as the sole carbon source (20). The natural substrate for Hv-p68 is not known, but the structurally similar alcohol oxidases are known to oxidize primary alcohols irreversibly to toxic aldehydes $(17,24)$. Overproduction of Hv-p68 and putative accumulation of toxic intermediates was proposed as a possible mechanism underlying the disease phenotype of virus-infected $H$. victoriae isolates (20). Overexpression of the Hv-p68 gene in virus-free fungal isolates, however, resulted in a significant increase in colony growth and no disease phenotype (this study). Thus, overproduction of the Hv-p68 protein per se is not sufficient to induce the disease phenotype in the absence of virus infection. If the function of Hv-p68 is similar to that of the homologous alcohol oxidases of methylotrophic yeasts or other filamentous fungi $(17,24)$ (i.e., irreversible oxidation of primary alcohols into aldehydes), then overproduction of Hv-p68 could lead to an accumulation of toxic aldehydes and development of disease phenotype. The finding that colonies over- producing the Hv-p68 protein did not exhibit the disease phenotype and grew more rapidly than the nontransformed WT and the empty vector-transformed control (this study) suggests that accumulation of toxic aldehydes did not occur, probably

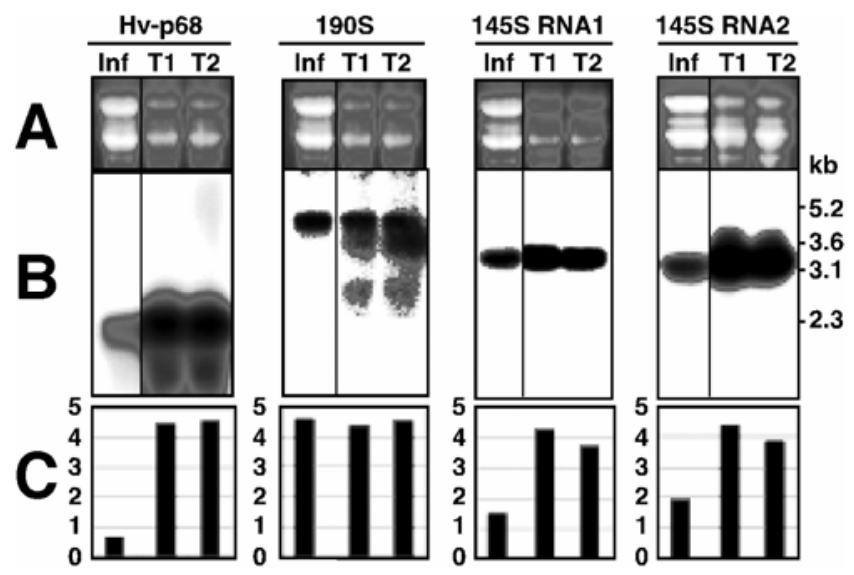

Fig. 5. Effect of $H v-p 68$ overexpression on virus content in a naturally virusinfected isolate. Northern blot hybridization analysis of total RNA from a nontransformed virus-infected isolate (Inf) and its two transformants, T1 and T2, which overexpress $H v-p 68$. Total RNA $(20 \mu \mathrm{g})$ was fractionated on denatured agarose gel and transferred to Nylon membranes. A, Ethidium bromide staining of rRNA is shown as loading control. B, Four separate blots of the total RNA samples were produced and individually hybridized to ${ }^{32} \mathrm{P}-$ labeled cDNA probes to either $H v-p 68$, Hv190S dsRNA, Hv-145SV dsRNA1, or Hv145S dsRNA2. C, The images generated by exposure of the blots to a phosphorimager screen were visualized by Phosphorimager 445 S1 system (Molecular Dynamics) and quantified with the gel ImageQuant 5.0 program.

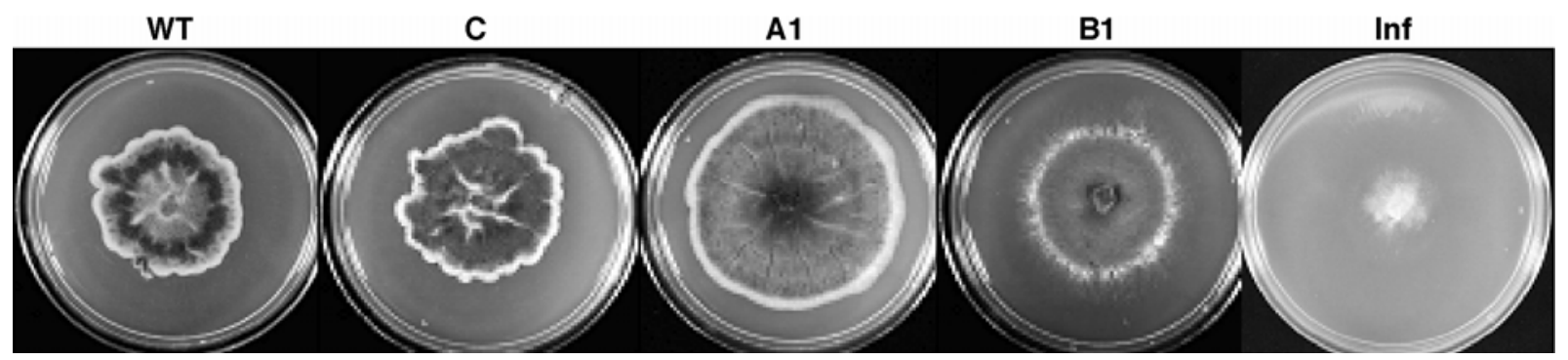

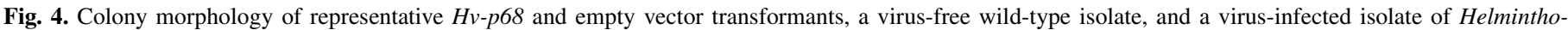

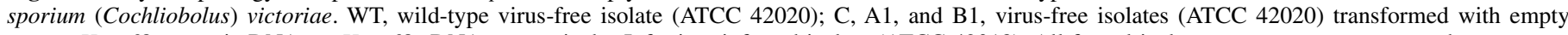

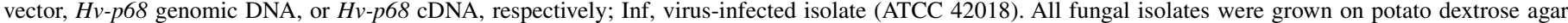
containing $0.5 \%$ (wt/vol) yeast extract medium for 7 days prior to photography.

TABLE 1. Growth comparisons between the wild-type virus-free isolate (WT) and the Hv-p68 transformants (Trans)

\begin{tabular}{|c|c|c|c|c|c|c|c|c|c|c|}
\hline \multirow[b]{2}{*}{ Trans } & \multirow[b]{2}{*}{ Colony $(\mathrm{mm})^{\mathrm{a}}$} & \multicolumn{9}{|c|}{ Mean of difference \pm SE between transformants ${ }^{b}$} \\
\hline & & $\mathrm{C}^{\mathrm{c}}$ & A1 & A2 & A3 & A4 & A5 & B1 & B2 & B3 \\
\hline WT & $54 \pm 0.0$ & $2.0 \pm 0.7$ & $18 \pm 1.0 * *$ & $18 \pm 1.2^{* *}$ & $6 \pm 2.1$ & $17 \pm 0.9 * *$ & $17 \pm 1.3 * *$ & $3 \pm 2.6$ & $8 \pm 0.9$ & $3 \pm 2.3$ \\
\hline $\mathrm{C}$ & $56 \pm 1.2$ & $\ldots$ & $16 \pm 1.2 * *$ & $16 \pm 1.3^{* *}$ & $8 \pm 2.2 *$ & $16 \pm 1.1 * *$ & $16 \pm 1.5 * *$ & $5 \pm 2.7$ & $9 \pm 1.1 * *$ & $5 \pm 2.4$ \\
\hline A1 & $72 \pm 1.7$ & $\ldots$ & $\ldots$ & $4 \pm 1.5$ & $18 \pm 2.3 * *$ & $3 \pm 1.3$ & $4 \pm 1.7$ & $13 \pm 2.8 * *$ & $22 \pm 1.3 * * *$ & $14 \pm 2.5^{* *}$ \\
\hline $\mathrm{A} 2$ & $72 \pm 2.0$ & $\ldots$ & $\ldots$ & $\ldots$ & $17 \pm 2.4 * *$ & $3 \pm 1.5$ & $4 \pm 1.8$ & $13 \pm 2.9 * *$ & $22 \pm 1.5^{* * *} *$ & $14 \pm 2.6^{* *}$ \\
\hline A3 & $48 \pm 3.6$ & $\ldots$ & $\ldots$ & $\ldots$ & $\ldots$ & $30 \pm 2.3 * *$ & $30 \pm 2.5^{* *}$ & $12 \pm 0.3$ & $5 \pm 2.3$ & $11 \pm 3.1$ \\
\hline A4 & $71 \pm 1.5$ & $\ldots$ & $\ldots$ & $\ldots$ & $\ldots$ & $\ldots$ & $4 \pm 1.6$ & $3 \pm 2.8^{*}$ & $22 \pm 1.2^{* * *}$ & $14 \pm 2.5^{* *}$ \\
\hline A5 & $71 \pm 2.3$ & $\ldots$ & $\ldots$ & $\ldots$ & $\ldots$ & $\ldots$ & $\ldots$ & $12 \pm 3.0 * *$ & $21 \pm 1.6^{* * * *}$ & $13 \pm 2.7 * *$ \\
\hline B1 & $51 \pm 4.6$ & $\ldots$ & $\ldots$ & $\ldots$ & $\ldots$ & $\ldots$ & $\ldots$ & $\ldots$ & $3 \pm 2.8$ & $9 \pm 3.5$ \\
\hline B2 & $46 \pm 1.5$ & $\ldots$ & $\ldots$ & $\ldots$ & $\ldots$ & $\ldots$ & $\ldots$ & $\ldots$ & $\ldots$ & $11 \pm 2.5$ \\
\hline B3 & $51 \pm 4.0$ & $\ldots$ & $\ldots$ & $\ldots$ & $\ldots$ & $\ldots$ & $\ldots$ & $\ldots$ & $\ldots$ & $\ldots$ \\
\hline
\end{tabular}

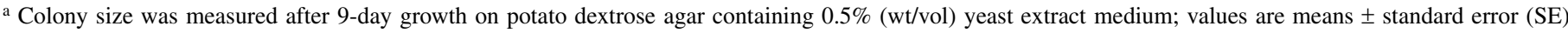
$(n=3)$.

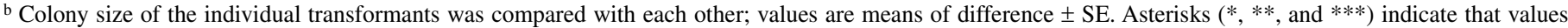
are significantly different $(P<0.05,0.01$, and 0.001 , respectively).

c Vector-only transformed control. 
due to assimilation into carbohydrates via the xylulose monophosphate pathway (17).

Hv-p68, which co-purifies with viral dsRNA (21), is a multifunctional protein with alcohol oxidase, protein kinase, and RNAbinding activities (20,21; S. A. Ghabrial, unpublished data). The RNA-binding activity of Hv-p68 has been demonstrated by gel mobility shift and northwestern blot analysis (20,21). Furthermore, the RNA binding domain of Hv-p68 was mapped to the Nterminal region that contains the ADP-binding domain (20). Because dsRNA-binding proteins are known to sequester dsRNA and suppress antiviral host defense mechanisms (11), it is possible that overexpression of the dsRNA-binding protein Hv-p68 may lead to the induction of the disease phenotype by suppressing host defense. This idea is consistent with our finding that overexpression of $H v-p 68$ led to enhancement in the accumulation of Hv145S dsRNA.

In northern hybridization analysis of total RNA from $H v-p 68$ cDNA or genomic DNA transformants, there were both 2.1- and 2.8-kb Hv-p68 transcripts, with the 2.8-kb transcript the most common. The 2.1-kb transcript is the size predicted for Hv-p68 mRNA (20), whereas the $2.8-\mathrm{kb}$ transcript contains the trpC terminator sequence in addition to Hv-p68 coding sequences. It is not clear why the terminator sequences were not cleaved prior to polyadenylation, because the $2.8-\mathrm{kb}$ transcript is polyadenylated. Although problems with the use of the $\operatorname{trpC}$ terminator sequence are not known, we also are unaware of any detailed analysis of transgene transcripts for trpC terminator sequence. Nevertheless, the $2.8-\mathrm{kb}$ transcript was translated properly and its translation product was indistinguishable from that of the authentic $2.1-\mathrm{kb}$ Hv-p68 mRNA. It is well known that many higher eukaryotic genes are transcribed well beyond the polyadenylation site (the consensus sequence AAUAAA) prior to cleavage $(\approx 20 \mathrm{bp})$ and the addition of poly(A) tail to the mature mRNA (9). The polyadenylation signals in filamentous fungi, however, are ill defined (9), and fungal transformation vectors do not necessarily carry heterologous terminator sequences $(14,23)$.

The finding that fungal isolates transformed with intron-containing $H v-p 68$ genomic DNA accumulated significantly higher levels of $H v-p 68$ transcripts than those transformed with the intronless $H v-p 68$ cDNA construct is of interest. The phenomenon of intron-mediated enhancement (IME) of gene expression has been well documented in various systems, including plants (18), insects (13), and mammals (4), but not filamentous fungi. Thus, it is worthwhile to examine in more detail the observations made in this study regarding putative IME in fungi, because IME could be exploited for improvement of heterologous gene expression in filamentous fungi.

The $H$. victoriae-virus system is well characterized and provides a useful model system for studies on virus-host interactions in a plant-pathogenic fungus $(7,8)$. A major attribute of this system is the fact that the virus-infected $H$. victoriae isolates exhibit a disease phenotype, which is uncommon among fungal viruses (6). Modulation of fungal gene expression and alteration of phenotypic traits as a consequence of mycovirus infection are poorly understood, with the exception of the chestnut blight fungus-hypovirus system $(1,5)$. We previously have demonstrated that the fungal gene $H v-p 68$ is upregulated as a result of virus infection and proposed that upregulation of this gene may play a role in virus pathogenesis $(20,21)$. In the present article, we showed that the mere accumulation in virus-free fungal isolates of higher levels of the Hv-p68 protein could not account for the development of the disease phenotype. It is possible that an interaction between virus and Hv-p68 is necessary. This idea is supported by the finding that overproduction of Hv-p68 in a virus-infected isolate enhanced the accumulation of the chrysovirus Hv145SV dsRNA (this study). Furthermore, these results are consistent with our earlier report that Hv-p68 co-purified with dsRNA, mainly that of the Hv145SV (21). However, the role of Hv145SV in the development of the disease phenotype is not yet clear. Considering the multifunctional nature of the Hv-p68 protein, additional studies are needed to determine whether or not $H v-p 68$ upregulation has a role in viral pathogenesis.

\section{ACKNOWLEDGMENTS}

This work was supported in part by Grant Agreement 2001-3531910010 from the United States Department of Agriculture National Research Initiative Competitive Research Program (to S. A. Ghabrial) and is published with the approval of the of the Director of the Kentucky Agricultural Experiment Station as Journal Article 04-12-054.

\section{LITERATURE CITED}

1. Allen, T. D., and Nuss, D. L. 2004. Specific and common alterations in host gene transcript accumulation following infection of the chestnut blight fungus with mild and severe hypoviruses. J. Virol. 78:41454155.

2. An, Z. Q., Farman, M. L., Budde, A., Taura, S., and Leong, S. A. 1996. New cosmid vectors for library construction, chromosome walking and restriction mapping in filamentous fungi. Gene 176:93-96.

3. Balance, D. J. 1986. Sequences important for gene expression in filamentous fungi. Yeast 2:229-236.

4. Buchman, A. R., and Berg, P. 1988. Comparison of intron-dependent and intron-independent gene expression. Mol. Cell Biol. 8:4395-4405.

5. Dawe, A. L., and Nuss, D. L. 2001. Hypoviruses and chestnut blight: Exploiting viruses to understand and modulate fungal pathogenesis. Annu. Rev. Genet. 35:1-29.

6. Ghabrial, S. A. 1986. A transmissible disease of Helminthosporium victoriae: Evidence for a viral etiology. Pages 163-176 in: Fungal Virology. K. W. Buck, ed. CRC Press, Boca Raton, FL.

7. Ghabrial, S. A. 2001. Molecular basis of disease in a virus-infected plant pathogenic fungus. (Abstr.) Phytopathology 91(suppl.):S149.

8. Ghabrial, S. A., Soldevila, A. I., and Havens, W. M. 2002. Molecular genetics of the viruses infecting the plant pathogenic fungus Helminthosporium victoriae. Pages 213-236 in: Molecular Biology of DoubleStranded RNA: Concepts and Applications in Agriculture, Forestry and Medicine. S. Tavantzis, ed. CRC Press, Boca Raton, FL.

9. Gurr, S. J., Uncles, S. E., and Kinghorn, J. R. 1987. The structure and organization of nuclear genes of filamentous fungi. Pages 93-139 in: Gene Structure in Eukaryotic Microbes. J. Kinghorn, ed. IRL Press, London.

10. Huang, S., Soldevila, A. I., Webb, B. A., and Ghabrial, S. A. 1997. Expression, assembly and proteolytic processing of Helminthosporium victoriae 190S totivirus capsid protein in insect cells. Virology 234: 130-137.

11. Lichner, Z., Silhavy, D., and Brgyan, J. 2003. Double-stranded RNAbinding proteins could suppress RNA interference-mediated antiviral defenses. J. Gen. Virol. 84:975-980.

12. Meehan, F., and Murphy, H. C. 1946. A new Helminthosporium blight of oats. Science 104:413.

13. Meredith, J., and Storti, R. V. 1993. Developmental regulation of the Drosophila tropomysin II gene in different muscles is controlled by muscle-type-specific intron enhancer elements and distal and proximal prompter control elements. Dev. Biol. 159:500-512.

14. Mönke, E., and Schäfer, W. 1993. Transient and stable gene expression in the fungal maize pathogen Cochliobolus heterostrophus after transformation with the $\beta$-glucuronidase (GUS) gene. Mol. Gen. Genet. 241:7380 .

15. Osherov, N., and May, G. S. 1998. Optimization of protein extraction from Aspergillus nidulans for gel electrophoresis. Fungal Genet. Newsl. 45:38-40.

16. Psarros, E. E., and Lindberg, G. D. 1962. Morphology and respiration of diseased and normal Helminthosporium victoriae. Phytopathology 52: 693-699.

17. Reid, M. F., and Fewson, C. A. 1994. Molecular characterization of microbial alcohol dehydrogenases. Crit. Rev. Microbiol. 20:13-56.

18. Rose, A. B. 2002. Requirements for intron-mediated enhancement of gene expression in Arabidopsis. RNA 8:1444-1453.

19. Sambrook, J., and Russell, T. 2001. Molecular Cloning, A Laboratory Manual, 3rd ed. Cold Spring Harbor Laboratory, Cold Spring Harbor, NY.

20. Soldevila, A. I., and Ghabrial, S. A. 2001. A novel alcohol oxidase/RNAbinding protein with affinity for mycovirus double-stranded RNA from the filamentous fungus Helminthosporium (Cochliobolus) victoriae. J. Biol. Chem. 276:4652-4661. 
21. Soldevila, A. I., Havens, W. M., and Ghabrial, S. A. 2000. A cellular protein with an RNA-binding activity co-purifies with viral dsRNA from mycovirus-infected Helminthosporium victoriae. Virology 272:183190.

22. Straubinger, B., Straubinger, E., Wirsel, S., Turgeon, G., and Yoder, O. 1993. Versatile fungal transformation vectors carrying the selectable bar gene of Streptomyces hygroscopicus. Fungal Genet. Newsl. 39: 82-83.
23. Turgeon, B. G., Garber, R. C., and Yoder, O. C. 1987. Development of a fungal transformation system based on selection of sequences with promoter activity. Mol. Cell. Biol. 7:3297-3305.

24. Varela, E., Martínez, T., and Martínez, M. J. 1999. Molecular cloning of aryl-alcohol oxidase from the fungus Pleurotus eryngii, an enzyme involved in lignin degradation. Biochem. J. 341:113-117.

25. Yoder, O. C. 1988. Cochliobolus heterostrophus, cause of Southern corn leaf blight. Adv. Plant Pathol. 6:93-112. 